\title{
Assessment of Creative Writing: The Case of Singapore Secondary Chinese Language Curriculum
}

\author{
Chan Kwong Tung \\ Curriculum, Teaching \& Learning Academic Group, National Institute of Education, Nanyang Technological University, Singapore
}

Copyright (C) 2015 by authors, all rights reserved. Authors agree that this article remains permanently open access under the terms of the Creative Commons Attribution License 4.0 International License

\begin{abstract}
In Singapore and in elsewhere alike, educators nowadays are paying much more attention on the set of teaching and assessment recommendations called the $21^{\text {st }}$ century skills that include creativity at the policy, programmatic, school and classroom levels. As these education systems develop and respond to the demands of the new century, educators are facing many challenges. In general, educational assessment does not pay much attention to creativity. This is despite the global call for teaching and learning of $21^{\text {st }}$ century skills. There are many reasons to this phenomenon and it can be understood from the conceptual and practical level. At the conceptual level, there is indeed a dearth of research on how creativity can be assessed in language art writing. Teachers think that assessments of creativity writings are too subjective to make a fair judgment. That could be one of the many reasons why both formal and informal assessments of students' creativity writings are rare in Singapore and in elsewhere. In educational assessment terminology, this concerns the concepts of validity and reliability issues of assessing students' creativity in writings. Teachers find it challenging to design valid and conduct reliable assessment to assess students' creativity. Nevertheless, this article argues that if creative writings are valued in the $21^{\text {st }}$ century education, then valid and reliable assessment methods should be introduced in the language art education. In other words, the technical quality of assessing students' creative writings should be ensured. Using Singapore secondary school Chinese Language curriculum and assessment as an example, this article further illustrates and discusses the possible solutions to overcome these challenges in the assessment of creative writing.
\end{abstract}

Keywords Assessment, Creative Writing, Chinese Language, $21^{\text {st }}$ Century Skills, Analytical Rubric

\section{Introduction}

\subsection{Trends in Chinese Language Writing Assessment}

The purpose of Chinese Language (CL) writing assessment has witnessed some paradigm shifts over the last few decades. Many educators are not satisfied with solely checking on students' attainment in writing skills and language proficiency levels. For example, many mainland China scholars have expressed their views over the new 2011 CL syllabus and assessment. They think that the purpose of writing assessment should be expanded. It should be able to arouse students' interest to write. It should also motivate them to read more widely on a regular basis [1] [2] [3]. Indeed, according to the latest Compulsory Language Education Curriculum Standard developed by the Ministry of Education, People's Republic of China (2011) [4], language education should be "student-centred" and thus should allow students to have more freedom to express their thoughts in writings. They should be encouraged to write creatively and teachers should minimize their restrictions on students' expressions. Instead, teachers should build more room for students to write and allow them to display and assess their works. Teachers must constantly reflect on their problems in teaching writings and return the freedom of writing to students. Students should be pro-actively involved in writings and be able to write with style and creativity. The purpose of writing assessment has become more complex.

In Hong Kong, the teaching, learning and assessment of the CL writing have also seen some changes since the announcement of the new direction and development for CL assessment by the Hong Kong Examinations and Assessment Authority (HKEAA) in 2007. The new syllabus and assessment define writing skills to encompass three major aspects [5]. The first aspect concerns with students' ability to complete the writing process. This may include analyzing the questions, planning the plots, expressing their thoughts and revising the final piece of work. The second aspect concerns with using various types of expression. These may include all the different genres and writing styles. The third aspect concerns with writing skills which would allow writers to reach specific objectives and meanings. These may include functional writings and literary creations. Apart from these three major aspects of writing skills, it is also important to note that writing assessment also implicates 
students' observation skills, creative thinking skills and communication skills. In particular, to assess students' creative thinking skills in writing requires the questions to be open. This will allow them to have more room to decide the theme, focus, gist and substance of their essay [6]. In other words, the questions or constructs of the assessment should not dictate the theme or focus of writing, instead, it should be decided by students' logical and creative interpretation. Similar to mainland China, the trend in writing assessment has shifted away from mainly to summarize students' level of attainment in CL writing. The purpose of writing assessment has expanded over the years.

\subsection{Technical Quality of Assessing Students' Creative Writing}

The purpose of writing assessment may have expanded over the years, however, educational assessment still does not pay much attention to creativity in general [7]. This is despite the global call for teaching and learning of $21^{\text {st }}$ century skills that include creativity. There are many reasons to this phenomenon and it can be understood from the conceptual and practical level. At the conceptual level, there is indeed a dearth of research on how creativity can be assessed in language art writing [8]. Teachers think that assessments of creativity writings are too subjective to make a fair judgement [9] [10] [11]. That could be one of the many reasons why formal assessments of students' creativity writings are rare in Singapore and in elsewhere. In educational assessment terminology, this concerns the concepts of validity and reliability issues of measuring or evaluating students' creativity in writings. Teachers find it challenging to design valid and conduct reliable assessment to measure or evaluate students' creativity. Nevertheless, this article argues that if creative writings are valued in the $21^{\text {st }}$ century education, then valid and reliable assessment methods should be explored and introduced in the language art education. In other words, the technical quality of assessing students' creative writings should be ensured. Using Singapore secondary school Chinese Language (CL) curriculum as an example, this article further illustrates and discusses the possible solutions to overcome this challenge.

\subsection{Tension in Assessment Practice}

At the practical level, teachers always find tension and contradiction between assessments in language education. For example, Deng and Carless (2010) [12] have observed contradictions in language teaching and examinations amongst the language teachers in China. While the impetus leans towards a more communicative language teaching (CLT) curriculum and task-based language teaching (TBLT) in English, they tend to react to these calls for changes according to their personal philosophies. Their study proves that the prevailing examination-oriented culture has great influence on pedagogy likewise to the Confucian-heritage contexts, such as China and Hong Kong where examination-oriented culture is firmly rooted. Pedagogic and assessment innovations have not much room for implementation.

Similarly, Scarino (2013) [13] has discussed the tension of two "contrasting paradigms" in language assessment. On one hand, there is the "traditional assessment" which tends to be aligned with the cognitive views of learning and psychometric testing. On the other hand, there is the "alternative assessment" which tends to be aligned with sociocultural views of learning (Scarino, 2013, p.312) [14]. Assessment authority usually favours the former paradigm because it is more reliable and is ideal for measuring students' learning. Contrastingly, the sociocultural views of learning favour the latter where their belief is grounded on assessment that should be carried out over a period of time in a variety of ways. Obviously, these contrasting paradigms created tension for classroom teachers to carry out instructional programmes and assessment. In the call for the $21^{\text {st }}$ century education, creativity assessment would also encounter such challenges. While majority stake-holders of education acknowledge the importance of cultivating students' creativity, it is not apparent at the national examinations despite the call for $21^{\text {st }}$ century skills assessment that emphasizes creativity at the policy level. As such, teachers are caught in situations where they struggle to decide what kinds of teaching and assessment to employ due to multiple considerations. Should they response to the global call for $21^{\text {st }}$ century skills or stick to the traditional language teaching and assessment? In the "performativity" culture of education, many teachers and schools would focus more on the high-stakes national examinations rather that promoting creativity in their respective subject areas. This article argues that unless this tension is resolved, teachers will just do "lip-service" to the call for $21^{\text {st }}$ century teaching and assessment. The teaching and assessment of creativity at the classroom (formative) and national level (summative) will continue to be undervalued. This article further suggests ways to reconcile teachers' assessment tension when teaching creativity in writings.

\section{Past Studies on Assessment of Creativity Writing}

\subsection{Creativity as a Concept}

According to Sternberg (2001) [15], creativity refers to the potential to produce novel ideas that are task-appropriate and high in quality (p. 360). One very important idea evolves from this definition. Both "task-appropriateness" and "high quality" involve subjective judgement. "Who" judge "what" is "appropriate" and "high in quality"? Obviously, the contextual factors seem to be a key component in this definition. In the same vein, Plucker, Beghetto and Dow (2004) [16] define creativity as "the interaction among aptitude, process, and environment by which an individual or 
group produces a perceptible product that is both novel and useful as defined within a social context" (p. 90). Plucker et al. (2004) [17] go on to describe the key components and explain the defining elements of creativity. For example, they specify the notion of "perceptibility" which could be interpreted as something that must be "observable". Similar to Sternberg's (2001) [18] idea, "social context" is the key determinant of creativity. Whether a process, action, person or product is judged as creative will be heavily determined by the social values of the context. Again, this idea implies that creativity is contextual and in different context, the definition and view may be different. Indeed, Csikszentmihalyi (1996) [19] also opines that creativity is only meaningful in the context of a system that judges it. Therefore, what is creative in one context may not be in another context. Even within the same context, such as curriculum development and planning, creativity may be viewed very differently depending which philosophy and sociological paradigm the agents apply. These perspectives directly affect the epistemology about how creativity can be learnt [20]. The direct implication for such an idea is that the "task-appropriateness" will set the assessment criteria the final product must fall within, in order to be considered creative.

\subsection{Assessing Creativity in Education}

So what should be the criteria when assessing students' creativity? How should educators approach it? These can get very complicated and messy if they do not delimit or define creativity in the respective learning disciplines. Adding on to the confusion, there are also different levels of creativity, such as the Four C Model of Creativity (mini-c, little-c, Pro-C and Big-C) advocated by Kaufman \& Beghetto (2009) [21]. In fact, before educators even think about what criteria should be used to assess students' creativity, they should actually work out a framework for creativity assessment. The work done by Blamires and Peterson (2014) [22] in the United Kingdom provided a very good example of how educators can define and develop creativity, as well as monitoring assessment, taking into account of a number of enabling contextual factors.

The teaching and assessment of creativity depend very much on how educators understand and define "creativity" in education within various contexts. However, defining creativity is always problematic because "the very nature of creativity in education remains ambiguous" (Craft, 2005, p. 226) [23]. Many scholars have attempted to define creativity in education. Goodwin and Miller (2013) [24], having summarised and combined the various definitions of creativity by Guilford (1950) [25], Cropley (2006) [26], Finke, Ward, and Smith (1992) [27], as well as Kaufman and Sternberg (2007) [28], concluded that creativity appears to require "a yin and a yang". This would mean that both divergent and convergent thinking should be valued in schools. Indeed, this take is both approachable and applicable in school context for two reasons. First, schools nowadays are still very subject-dominated where content knowledge forms the bunk of the curriculum and teaching. Students' acquisition of subject content knowledge builds the foundation for activating convergent thinking. Convergent thinking is one that focuses on well-established answers to questions. It is aimed at looking for a single best, or usually correct or standard answers [29]. For content subjects such as Language Art, Social Studies, Mathematics and Science at the elementary levels, this approach of teaching are a commonplace in both Singapore and in elsewhere. If position and design appropriately, these subjects can form the base for creative teaching and learning. As Brookhart (2010) [30] has suggested earlier, one of the most prominent characteristics of creative students is that they are able to "put things together in new ways". Students will need to "know the things", that is, to learn "something" before they can put them together in new ways.

\subsection{Previous Work in Assessing Creative Writing}

Brookhart (2013) [31] has long proposed to use rubrics for assessing creativity because they help both teachers and students clarify criteria for creative learning and production. The rubrics also show what the continuum of creative performance or how the final product looks like, from imitative to very creative. As such, rubrics are useful for sharing with students what they are targeting, where they are currently, and what they should do to be more creative in their next performance. In other words, they are indicators of learning outcomes. According to Brookhart (2013, p4) [32], "a rubric is a coherent set of criteria for students' work that includes descriptions of levels of performance quality on the criteria". In the language art teaching, rubrics are commonly used to assess students' performance in writing, speaking, interactions and project works.

Blomer (2011) [33] also opined that the most useful idea in assessment of creative writing is to integrate all the tools of assessment. As for the problem of subjectivity, she thought that it could be solved by employing a rubric and grading grid work which is best in conjunction with peer and teacher feedbacks, interviews with teachers, and a portfolio. Portfolios allow students to combine the many kinds of feedback, review and revise their work and come closer to that writing vision through close critical edits of their work. Burroway (2011) [34], Griffin and Anh (2005) [35], Morris and Sharpin (2013) [36], Mozaffari (2013) [37], among many others, had also recommended the use of rubrics to assess creativity writing. For example, Morris and Sharpin (2013) [38] has argued that criterion-reference methods such as the analytical marking keys should be preferred if valid, fair and reliable assessment methods are sought. Burroway (2011) [39] and Mills (2006) [40] had further proposed image, voice, characterization and story to be the four important qualities or criteria to be included in the assessment of creative writing. These qualities are covered in the Singapore secondary CL curriculum.

Building on the definition and the fundamentals of 
creativity, together with previous work in assessing creative writing, the Analytical Rubric for Assessing Creativity in CL Writing can be developed. It will be discussed later.

\section{Chinese Language Curriculum Planning In Singapore}

\subsection{The Bilingual Policy and Chinese Language Curriculum}

The Bilingual Policy, or the Mother Tongue Policy, is a cornerstone of the Singapore education system. English is the official first language and the medium of instruction in schools. All students (except for some special cases) in the Singapore education system are required to take a "Mother Tongue" subject. This could be one of the three official languages: Chinese, Malay or Tamil. The choice is usually determined by the student's race. The Bilingual Policy was first introduced in 1956 and was fully implemented in 1965 after many rounds of fine-tuning. In the recent years, there were four reviews on the MTLs, which took placed in 1991, 1999, 2004 and 2010 respectively. The currently used 2011 CL Secondary School Syllabus was crafted very closely to the recommendations given by the 2010 Mother Tongue Languages Review Committee (MTLRC). Changing language environment and advances in the understanding and practice of teaching languages were the two major impetuses for the most recent MTLRC review. According to the review report, there has been a clear, long-term trend of increasing use of English Language as the dominant home language across all communities. For example, among ethnic Chinese students, the proportion of students whose first home language is English rose from 28\% in 1991 to $59 \%$ in 2010 (MOE, 2010, p.10) [41]. The MTLRC made study trips to many countries and spoke with educators, parents and students to understand their progress and to pick up learning points.

\subsection{Curriculum and Assessment Reforms in Singapore}

CL teaching and assessment in Singapore had met with many new challenges in the last few decades. The "Thinking Schools, Learning Nation" (TSLN) vision, the "Teach Less, Learn More" (TLLM) initiative, the call for students to be equipped with $21^{\text {st }}$ Century Competencies $\left(21^{\text {st }} \mathrm{CC}\right)$ and the four major reviews (in 1991, 1999, 2004 and 2010) on the Mother Tongue Language (MTL) by the Ministry of Education (MOE) have all called for a parallel change in the curriculum and advocated teaching and assessment to promote deeper understanding of knowledge, higher-order thinking skills and creativity. Therefore, a more balanced assessment system is needed to prepare students for the $21^{\text {st }}$ century. Many scholars have argued that Singapore schools need to equip and encourage teachers to adopt authentic assessment in teaching and learning so as to develop the students' higher-order thinking [42] [43] [44]. Koh and Gong (2008) [45] has reviewed that the assessment and teaching of Chinese in Singapore emphasizes drill and practice of basic linguistic knowledge and principles. The assessment tasks seldom engaged students in higher-order thinking, real world problem solving, and extensive communication.

\subsection{Curriculum Planning at the Programmatic Level}

The currently used secondary CL curriculum was implemented in 2011. In response to the curriculum and assessment reforms, reviews and critics mentioned above, the Curriculum Planning and Development Division (CPDD) of MOE has since taken the initiative to plan curriculum that is fit for the $21^{\text {st }}$ century. At the programmatic level, the MTL curriculum was designed and taught to develop proficient users who can communicate effectively using the language in real-life contexts and apply it in inter-personal communication, listening and reading for comprehension, and presenting in spoken and written forms. To achieve this, the MTL curriculum should align teaching and testing to achieve proficiency. It should also enhance different provisions for learners of different abilities (MOE, 2010, p.14) [46]. It is not difficult to observe that the initiative at the policy level is very much well translated into programmatic level. In order to nurture active learners, the curriculum has to be engaging. The learners will feel more engaged and motivated to learn if the instructional programme is authentic, interesting and meaningful (for example, more spoken interaction and written interaction). Furthermore, if students saw a close matching between the curriculum and assessment, a positive impact on student learning is ensured and proficient users will be produced. Indeed, in the case of the secondary CL curriculum, specified learning points (in terms of language skills that include listening, speaking, reading and writing) are clearly spelt out and systematically taught. Assessment for learning is put in place for teachers to monitor students' learning progress. These include checking for understanding exercises, small quizzes, self-check exercises (self-assessment) and workbook exercises (usually mark by teachers). Writing skills are systematically planned according to different genres (narrative, descriptive, expository and argumentative essay). Although creative writing skills could be developed via all genres, they are generally more prominent in the narrative and descriptive essays. An analytical rubric (see Annex A) encompassing qualities of creative writing (criteria) and categories of achievement (bands) could be developed to assess students learning at different stages of their study. However, teachers must have the assessment literacy to optimise the potential of the rubric.

\section{Discussion and Suggestions}




\subsection{Addressing the Challenges in Assessment of Creative Writing}

The Analytical Rubric for Assessing Creativity in CL Writing (Annex A) may be able to resolve the challenges when assessing creativity. The two key sources of evidence of technical quality for assessment are validity and reliability [47]. Validity refers to whether an assessment task measures what it purports to measure (Kelley, 1927, p.14) [48]. In the case of assessing creative writing in the secondary CL curriculum, the construct must be able to assess or test students' ability in creative writings. This article has already defined what is "creative writing" earlier based on Burroway (2011) [49] and Mills' (2006) [50] works. Now, it is to ensure that the assessment task is able to assess or measure students' creative writing skills. According to the Secondary CL Assessment Guide by CPDD, MOE (2014) [51], assessment tasks at the summative stage are designed with the whole year assessment plan, Table of Specification (TOS) and the assessment rubrics in mind. In this way, the curriculum and assessment are closely aligned. To ensure validity, the criteria in the rubric are the learning points (writing skills) taught in the curriculum. Naturally, the assessment task requires students to use "creative writing skills" instead of "flat writing". As mentioned earlier, in order to promote creative writing, specified learning points in terms of "creative writing skills" are taught in the curriculum. Depending on the purpose, teachers may use more specified or general rubrics to assess students learning during the course of their study. For example, the assessment task required them to produce a product that demonstrated their understanding of the learning of "creative" writing skills during their CL lessons. Instead of using "flat writing", students are asked to perform their creative writing skills within the parameters of image, voice, characterization and story [52] [53] which were taught explicitly in the curriculum. For example, under the teaching of image, instead of directly describing a scenic place (i.e flat writing), the curriculum direct student to learn and use "multi-sensory" writing skills (i.e creative writing) to complete a piece of writing. Another example below (drew from Higher CL 1A textbook) will illustrate the difference between creative writing ("action" characterization) and flat writing (direct characterization):

Writing 1: Aunt Ann deliberately showed off her big diamond ring to the surrounding people.

Writing 2: Aunt Ann is a boastful lady.

Writing 1 is an "action" characterization which shows what a character does through the narrative. This type of indirect characterization gives the readers some information and allows them to draw their own conclusion about the kind of person the character is. On the other hand, Writing 2 is a direct characterization in which the writer directly informs the readers what the character is like. In the secondary CL curriculum, image, voice, characterization and story are explicitly taught so that students can employ these skills to write creative essay. While it is obvious that creative writing skills are planned in the curriculum, it is often the assessment which direct what students learn in their classrooms.

In the same way as to how Koh (2008) [54] argued for technical quality in authentic assessment, this article also argue that if the relevant authorities want teachers and stakeholders of education to have confidence in creativity assessment practices, they would need to explore how this rubric judging is of good technical quality. Teachers' moderation is the answer to this call "to ensure the objectivity and comparability of judgement-based scoring of student work" (Koh, 2008, p.49) [54]. First, the CL teachers have to be trained to be conversant with the rubric. They need to achieve $70 \%$ and above in their inter-rater reliability. Reliability refers to the consistency of assessment. Second, student work samples are given to two teachers for them to score individually. They will need to discuss to come to an agreement if there is discrepancy. They will need to reflect on their assessment practice during the scoring process. The two teachers' scores are then entered into the Statistical Package for the Social Sciences (SPSS) or other relevant software, according to each criterion and the percentage of agreement between them could be calculated. In this way, the reliability of the assessment task is ensured at $70 \%$ or above.

\subsection{Reconciling Teachers' Assessment Tension}

The tension experienced by teachers when assessing students" creative writing may be between "sound assessment" and "essential assessment". The former usually exhibits a more balance use of assessment that includes alternative assessment, authentic assessment and performance assessment (task-based language assessment). In the case of language teaching, it motivates and encourages students to learn the language, even after they have left the education system. It appears to be more flexible, adaptable and informal. On the other hand, the latter mainly focus on the test content and the skills to score high in national examinations. Teachers usually train students to answer those specific examination questions so that they become "examination smart". It discourages students from learning and appears to be highly rigid, structured and formal.

To reconcile this tension, the authority has to build in and promote creative writing in both formative and summative assessment at the policy, programmatic and school levels. If educators truly value creative writing, it should be included as a learning outcome in the curriculum and assessment so that there will be no more "lip service" in assessing creative writing or any other $21^{\text {st }}$ century skills alike. In addition, teachers' sustainable training and professional development in assessment literacy are also vital to ensure technical quality of teachers' assessment task and judgment. Time and resources need to be set aside for their active participations in professional development workshops.

\section{Conclusions}

In conclusion, this article has highlighted the challenges in 
creativity assessment in general and in language teaching, particularly in writing. Using Singapore secondary school CL curriculum and assessment as an example, this article illustrates and discusses the possible solutions of developing the Analytical Rubric for Assessing Creativity in CL Writing to overcome these challenges. It is argued that while the rubric may be valid to assess student's creative writing skills, it is the technical quality in assessment that will lead the teachers and stakeholders of education to have confidence in creativity assessment practices. This article further argued that teachers' assessment literacy is vital to ensure the technical quality in assessment and therefore time and resources need to be set aside for teachers' active participations in professional development workshops.

\section{Appendix A}

\section{中学华文 (快脻课罣) 特定评量表 (创造性思维的写作) Analytical Rubric for Assessing Creativity in CL Writing}

\begin{tabular}{|c|c|c|c|c|c|c|}
\hline \multicolumn{2}{|c|}{ 准则 等级 } & $\mathbf{A}$ & B & C & D & $\mathbf{E}$ \\
\hline \multirow{2}{*}{$\begin{array}{c}\text { 背景形 } \\
\text { 象的描 } \\
\text { 写* }\end{array}$} & $\begin{array}{c}\text { 五官感知的调 } \\
\text { 动 }\end{array}$ & $\begin{array}{c}\text { 调动很恰当, 使 } \\
\text { 整体描写的人和 } \\
\text { 物更具体、生动 } \\
\text { 和突出 }\end{array}$ & $\begin{array}{l}\text { 调动恰当, 使描 } \\
\text { 写的人和物更具 } \\
\text { 体、生动和突出 }\end{array}$ & $\begin{array}{c}\text { 调动还算恰当, } \\
\text { 使描写的人和 } \\
\text { 物更具体 }\end{array}$ & $\begin{array}{c}\text { 调动不恰当, 不 } \\
\text { 能使描写的人和 } \\
\text { 物更具体、生动 } \\
\text { 和突出 }\end{array}$ & $\begin{array}{l}\text { 没有调动五 } \\
\text { 官感知 }\end{array}$ \\
\hline & $\begin{array}{c}\text { 修辞手法的运 } \\
\text { 用 (如 : 比喻、 } \\
\text { 拟人 ) }\end{array}$ & $\begin{array}{l}\text { 运用的修辞很贴 } \\
\text { 切, 使意思更明 } \\
\text { 白, 表达更生动、 } \\
\text { 真切, 引起读者 } \\
\text { 丰富的联想 }\end{array}$ & $\begin{array}{l}\text { 运用的修辞贴 } \\
\text { 切, 使意思更明 } \\
\text { 白, 表达更生动、 } \\
\text { 真切, 引起读者 } \\
\text { 丰富的联想 }\end{array}$ & $\begin{array}{c}\text { 运用的修辞还 } \\
\text { 算贴切, 使意思 } \\
\text { 更明白, 表达更 } \\
\text { 真切 }\end{array}$ & $\begin{array}{c}\text { 运用的修辞不贴 } \\
\text { 切, 不能使意思 } \\
\text { 更明白, 表达更 } \\
\text { 生动、真切 }\end{array}$ & $\begin{array}{c}\text { 没有运用修 } \\
\text { 辞手法 }\end{array}$ \\
\hline \multirow{2}{*}{$\begin{array}{c}\text { 文章情 } \\
\text { 节的安 } \\
\text { 排* }\end{array}$} & 内容详略得当 & $\begin{array}{c}\text { 记述 / 描写详略 } \\
\text { 非常得当, 突出 } \\
\text { 了主题 } \\
\end{array}$ & $\begin{array}{l}\text { 记述 / 描写详略 } \\
\text { 得当, 突出了主 } \\
\text { 题 } \\
\end{array}$ & $\begin{array}{c}\text { 记述 / 描写详 } \\
\text { 略基本得当, 带 } \\
\text { 出了主题 }\end{array}$ & $\begin{array}{c}\text { 记述 / 描写详略 } \\
\text { 不得当, 无法带 } \\
\text { 出主题 }\end{array}$ & $\begin{array}{l}\text { 记述 / 描写 } \\
\text { 的内容没有 } \\
\text { 详略之分 }\end{array}$ \\
\hline & $\begin{array}{c}\text { 内容顺序的安 } \\
\text { 排 (如 : 倒叙、 } \\
\text { 插叙 ) }\end{array}$ & $\begin{array}{c}\text { 安排非常合理、 } \\
\text { 自然, 帮助了情 } \\
\text { 节的展开, 能引 } \\
\text { 人入胜 }\end{array}$ & $\begin{array}{l}\text { 安排合理、自然, } \\
\text { 帮助了情节的展 } \\
\text { 开, 能引人入胜 }\end{array}$ & $\begin{array}{c}\text { 安排还算合理， } \\
\text { 帮助了情节的 } \\
\text { 展开 }\end{array}$ & $\begin{array}{c}\text { 安排不合理, 无 } \\
\text { 法帮助情节的展 } \\
\text { 开 }\end{array}$ & $\begin{array}{c}\text { 内容没有顺 } \\
\text { 序的安排 }\end{array}$ \\
\hline $\begin{array}{l}\text { 人物的 } \\
\text { 塑造* }\end{array}$ & $\begin{array}{c}\text { 行动、肖像、 } \\
\text { 语言和心理描 } \\
\text { 写的运用 }\end{array}$ & $\begin{array}{c}\text { 运用的人物描写 } \\
\text { 非常恰当地表现 } \\
\text { 了人物的身份、 } \\
\text { 性格、思想感情 } \\
\text { 和内心世界 }\end{array}$ & $\begin{array}{c}\text { 运用的人物描写 } \\
\text { 恰当地表现了人 } \\
\text { 物的身份、性格、 } \\
\text { 思想感情和内心 } \\
\text { 世界 }\end{array}$ & $\begin{array}{c}\text { 运用的人物描 } \\
\text { 写基本表现了 } \\
\text { 人物的身份、性 } \\
\text { 格、思想感情和 } \\
\text { 内心世界 }\end{array}$ & $\begin{array}{c}\text { 运用的人物描写 } \\
\text { 不能表现人物的 } \\
\text { 身份、性格、思 } \\
\text { 想感情和内心世 } \\
\text { 界 }\end{array}$ & $\begin{array}{c}\text { 没有运用人 } \\
\text { 物描写 }\end{array}$ \\
\hline $\begin{array}{l}\text { 语文的 } \\
\text { 表达* }\end{array}$ & 词汇的运用 & $\begin{array}{c}\text { 词汇丰富, 使用 } \\
\text { 正确，极富感染 } \\
\text { 力 } \\
\end{array}$ & $\begin{array}{c}\text { 词汇相当丰富 }, \\
\text { 基本上使用正 } \\
\text { 确，富感染力 }\end{array}$ & $\begin{array}{c}\text { 词汇有限, 用词 } \\
\text { 还算正确 }\end{array}$ & $\begin{array}{l}\text { 词汇贫乏, 用词 } \\
\text { 不大正确 }\end{array}$ & $\begin{array}{l}\text { 词汇贫乏, } \\
\text { 用词不当 }\end{array}$ \\
\hline
\end{tabular}

*Adopted from Burroway (2011) and Mills' (2006) quality of creative writing (image / story / characterization / voice). 


\section{REFERENCES}

[1] Bao, Guofu. (2014). Some thoughts on the writing assessment. Literature Education, 9, 76-77.

[2] Lu, Guike. (2014). The current status of the middle school writing assessment and its strategies analysis. Education Circle, 31(163), 121-122.

[3] Wang, Xin. (2013). Discussion on the teaching of writing of the new secondary syllabus. Young Science, 2, 303.

[4] Ministry of Education of the People's Republic of China. (2011). Compulsory Language Education Curriculum Standard. Beijing Normal University Publishing Group.

[5] Chu, C. \& Shum, M.S.K. (2011). Learning and assessment of writing skills. In Shum, M.S.K., Law, D.Y.K., Lam, J. W.I. \& Chung, A.L.S. (Eds). New direction for Chinese language curriculum in Hong Kong: Learning and assessment. Hong Kong: Hong Kong University Press, 67-99.

[6] Chu, C. \& Shum, M.S.K. (2011). Learning and assessment of writing skills. In Shum, M.S.K., Law, D.Y.K., Lam, J. W.I. \& Chung, A.L.S. (Eds). New direction for Chinese language curriculum in Hong Kong: Learning and assessment. Hong Kong: Hong Kong University Press, 67-99.

[7] Kaufman, J. C., Plucker, J. A. \& Russell, C. M. (2012). Identifying and Assessing Creativity as a Component of Giftedness. Journal of Psychoeducational Assessment, 30 (1), 60-73.

[8] Austen, V. J. (2005). The value of creative writing assignments in English Literature courses. The International Journal for the Practice and Theory of Creative Writing, 2 (2), 138-150.

[9] Morris, G. \& Sharpin, E. (2013). The Assessment of Creative Writing in Senior Secondary English: A Colloquy Concerning Criteria. English in Education, 47 (1), 49-65.

[10] Randi, J. \& Jarvin, L. (2006). An "A" for Creativity: Assessing Creativity in the Classroom. Thinking Classroom, 7(4), 26-32.

[11] Singleton, J. (1992) 'Creative writing and assessment: A case study,' in M. Monteith and R. Miles, (eds) Teaching Creative Writing. Philadelphia: Open University Press.

[12] Deng, C. \& Carless, D. R. (2010). Examination Preparation or Effective Teaching: Conflicting Priorities in the Implementation of a Pedagogic Innovation. Language Assessment Quarterly, 7(4), 285-302.

[13] Scarino, A. (2013). Language assessment literacy as self-awareness: Understanding the role of interpretation in assessment and in teacher learning. Language Testing, 30(3), 309-327.

[14] Scarino, A. (2013). Language assessment literacy as self-awareness: Understanding the role of interpretation in assessment and in teacher learning. Language Testing, 30(3), 309-327.

[15] Sternberg, R. J. (2001). What Is the Common Thread of Creativity? Its Dialectical Relation to Intelligence and Wisdom. American Psychologist, 56(4), 360-362.
[16] Plucker, J. A., Beghetto, R. A. \& Dow, G. (2004). Why isn't creativity more important to educational psychologists? Potential, pitfalls, and future directions in creativity research. Educational Psychologist, 39, 83-96.

[17] Plucker, J. A., Beghetto, R. A. \& Dow, G. (2004). Why isn't creativity more important to educational psychologists? Potential, pitfalls, and future directions in creativity research. Educational Psychologist, 39, 83-96.

[18] Sternberg, R. J. (2001). What Is the Common Thread of Creativity? Its Dialectical Relation to Intelligence and Wisdom. American Psychologist, 56(4), 360-362.

[19] Csikszentmihalyi, M. (1996). Creativity: Flow and the psychology of discovery and invention. New York: Harper Collins.

[20] Welle-Strand, A. \& Tjeldvoll, A. (2003). Creativity, curricula and paradigms. Scandinavian Journal of Educational Research, 47 (2), 357-372.

[21] Kaufman, J. C., Plucker, J. A. \& Russell, C. M. (2012). Identifying and Assessing Creativity as a Component of Giftedness. Journal of Psychoeducational Assessment, 30 (1), 60-73.

[22] Blamires, M. \& Peterson, A. (2014). Can creativity be assessed? Towards an evidence-informed framework for assessing and planning progress in creativity. Cambridge Journal of Education, 44 (2), 147-162.

[23] Craft, A. (2006). Fostering creativity with wisdom. Cambridge Journal of Education, 36 (3), 337-350.

[24] Goodwin, B. \& Miller, K. (2013). Creativity requires a mix of skills. Educational Leadership, 70(5), 80-83.

[25] Guilford, J. P. (1950). Creativity. American Psychologist, 5, 444-454.

[26] Cropley, A. (2006). In Praise of Convergent Thinking. Creativity Research Journal, 18 (3), 391-404.

[27] Finke, R. A., Ward, T. B. \& Smith, S. M. (1992). Creative Cognition. Boston: MIT Press.

[28] Kaufman, J. C. \& Sternberg, R. J. (2007). Resource review: Creativity. Change, 39(4), 55-58.

[29] Cropley, A. (2006). In Praise of Convergent Thinking. Creativity Research Journal, 18 (3), 391-404.

[30] Brookhart, S. M. (2010). How to assess higher-order thinking skills in your classroom. Alexandria, VA: ASCD.

[31] Brookhart, S. M. (2013). How to create and use rubrics for formative assessment and grading. Alexandria, VA: ASCD.

[32] Brookhart, S. M. (2013). How to create and use rubrics for formative assessment and grading. Alexandria, VA: ASCD.

[33] Blomer, Y. (2011). Assessment in creative writing, Wascana Review, 43 (1), 61-73.

[34] Burroway, J. (2011). Imaginative writing: Elements of craft. New York: Penguin.

[35] Griffin, P. \& Anh, P. N. (2005). Assessment of Creative Writing in Vietnamese Primary Education. Asia Pacific Education Review, 6(1), 72-86.

[36] Morris, G. \& Sharpin, E. (2013). The Assessment of Creative 
Writing in Senior Secondary English: A Colloquy Concerning Criteria. English in Education, 47(1), 49-65.

[37] Mozaffari, H. (2013). An Analytical Rubric for Assessing Creativity in Creative Writing, Theory and Practice in Language Studies, 3 (12), 2214-2219.

[38] Morris, G. \& Sharpin, E. (2013). The Assessment of Creative Writing in Senior Secondary English: A Colloquy Concerning Criteria. English in Education, 47(1), 49-65.

[39] Burroway, J. (2011). Imaginative writing: Elements of craft. New York: Penguin.

[40] Mills, P. (2006). The Routledge creative writing coursebook. New York: Routledge.

[41] Ministry of Education, Singapore. (2010). 2010 Mother Tongue Languages Review Committee Report.

[42] Koh. K., Tan. C \& Ng. P.T. (2012). Creating thinking schools through authentic assessment: the case in Singapore. Educational Assessment, Evaluation and Accountability, 24, 135-149.

[43] Koh, K. H. (2011). Improving teachers' assessment literacy. Singapore: Pearson/Prentice Hall.

[44] Koh, K. H. \& Luke, A. (2009). Authentic and conventional assessment in Singapore schools: an empirical study of teacher assignments and student work. Assessment in Education: Principles, Policy \& Practice, 16(3), 291-318.
[45] Koh, K. H. \& Gong, W. (2008). Alternative assessment and the teaching of Mandarin Chinese to elementary school students in multilingual Singapore. Paper presented at the 2008 American Educational Research Association (AERA) conference in New York, USA.

[46] Ministry of Education, Singapore. (2010). 2010 Mother Tongue Languages Review Committee Report.

[47] Koh, K. H. (2008). Authentic assessment and its technical quality. In Tan, K \& Koh, K. H. (Eds). Authentic Assessment in School. Singapore: Prentice Hall, 34-58.

[48] Kelley, T. L. (1927). Interpretation of educational measurements. New York: Macmillan.

[49] Burroway, J. (2011). Imaginative writing: Elements of craft. New York: Penguin.

[50] Mills, P. (2006). The Routledge creative writing coursebook. New York: Routledge.

[51] Ministry of Education, Singapore. (2014). Assessment Guide for Secondary Chinese Language Curriculum (Revised).

[52] Burroway, J. (2011). Imaginative writing: Elements of craft. New York: Penguin.

[53] Mills, P. (2006). The Routledge creative writing coursebook. New York: Routledge.

[54] Koh, K. H. (2008). Authentic assessment and its technical quality. In Tan, K \& Koh, K. H. (Eds). Authentic Assessment in School. Singapore: Prentice Hall, 34-58. 